\title{
international
}

\section{review of social history}

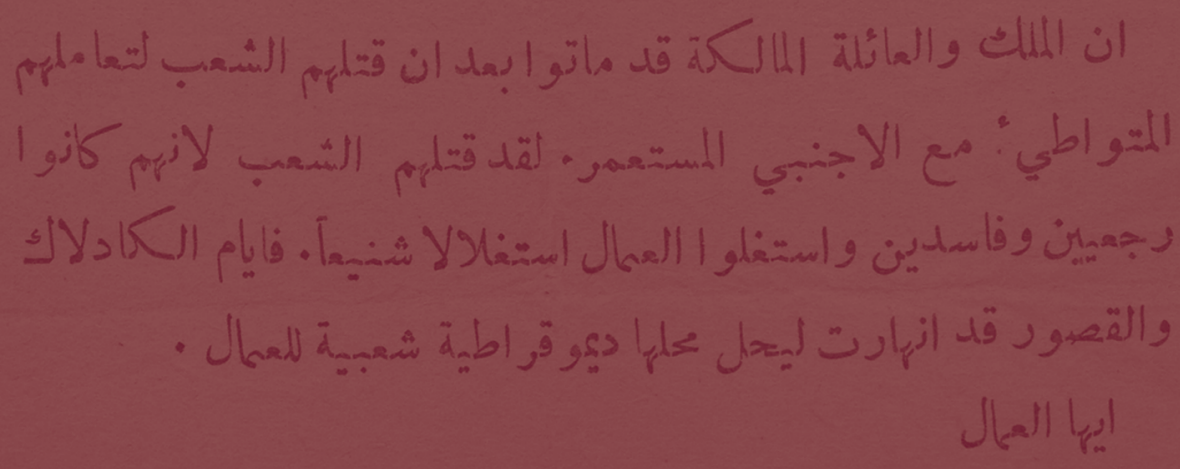

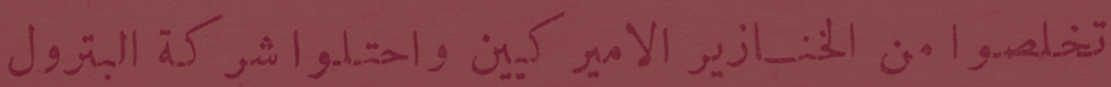

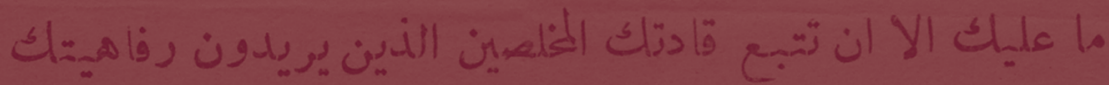

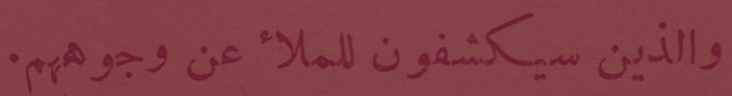

$$
\begin{aligned}
& \text { ايها المرب } \\
& \text { اتحدو اك' ان الجزيرة العربية للعرب. }
\end{aligned}
$$

published for the internationaal instituut voor sociale geschiedenis, amsterdam

\section{CAMBRIDGE UNIVERSITY PRESS}




\section{International Review of Social History \\ Published For the InTERnationaAl InstituUt voor Sociale Geschiedenis, Amsterdam}

\section{EXECUTIVE EDITOR}

David Mayer, Internationaal Instituut voor

Sociale Geschiedenis, Cruquiusweg 3I,

IoIg AT Amsterdam, The Netherlands

\section{Editorial CommitTeE}

Ravi Ahuja, Rossana Barragán Romano,

Stefano Bellucci, Ulbe Bosma,

Gita Deneckere, Ad Knotter,

Christine Moll-Murata,

Marcel van der Linden (Chair),

Elise van Nederveen Meerkerk

\section{EDitorial StafF}

Angèle Janse, Editorial Assistant

Jenneke Quast, Bibliography

\section{CORRESPONDING EDITORS}

Friedhelm Boll, Friedrich Ebert Stiftung, Bonn

Eileen Boris, University of California, Santa Barbara

David De Vries, Tel Aviv University

Nancy Green, EHESS, Paris

Michael Hall, Universidad Estadual de Campinas

David Howell, University of York

Elina Katainen, Helsinki
Amarjit Kaur, University of New England,

Armidale

Reinhart Kößler, Bochum

Friedrich Lenger, Justus-Liebig-Universität,

Giessen

Paolo Malanima, Università degli Studi di

Reggio Calabria

Siegfried Mattl, Institut fir Zeitgeschichte, Wien

Prabhu Mohapatra, New Delhi

Irina Novičenko, Center for Social History,

Moscow

Lars Olsson, Linnaeus University, Växjö

Ricardo D. Salvatore, Universidad Torcuato

di Tella

Lucy Taksa, Macquarie University, Sydney

\section{ADVISORY BoARD}

Eileen Boris, University of California,

Santa Barbara

Ute Frevert, Yale University

Manuel Pérez Ledesma, Universidad Autonoma de Madrid

Richard Price, University of Maryland

Wilfried Reininghaus, Nordrhein-Westfälisches

Staatsarchiv Münster

\section{SUBSCRIPTIONS}

International Review of Social History (ISSN 0020-8590) is published in three parts in April, August and December plus one special issue in December. Three parts plus one special issue form a volume. The subscription price (excluding VAT) of volume 59 (2014) which includes electronic access and delivery by air where appropriate is $£_{1} 86$ net (US\$316 in the USA, Canada and Mexico) for institutions; $£ 50$ net (US\$8I in the USA, Canada and Mexico) for individuals ordering direct from the publisher and certifying that the journal is for their own personal use. Single parts and the special issue are $£_{49}$ (US\$83 in the USA, Canada and Mexico) plus postage. An electronic only price available to institutional subscribers is $£$ I50 (US\$258 in USA, Canada and Mexico). EU subscribers (outside the UK) who are not registered for VAT should add VAT at their country's rate. VAT registered subscribers should provide their VAT registration number. Japanese prices for institutions are available from Kinokuniya Company Ltd, P.O. Box 55, Chitose, Tokyo 156, Japan.

Orders, which must be accompanied by payment, may be sent to a bookseller, subscription agent or direct to the publisher: Cambridge University Press, Journals Fulfillment Department, UPH, Shaftesbury Road, Cambridge CB2 8BS, UK; or in the USA, Canada and Mexico: Cambridge University Press, Journals Fulfillment Department, Ioo Brook Hill Drive, West Nyack, New York I0994-2133. Periodicals postage paid at New York, NY and at additional mailing offices. Postmaster: send address changes in USA, Canada and Mexico to International Review of Social History, Cambridge University Press, IOo Brook Hill Drive, West Nyack, New York I0994-2133.

Information on International Review of Social History and all other Cambridge journals can be accessed via journals.cambridge.org

Printed and bound by Bell \& Bain Ltd, Glasgow, UK

(C) Internationaal Instituut voor Sociale Geschiedenis 


\section{international \\ review of \\ social history}

Volume 59 Part 3 December 2014

\section{CONTENTS}

ArTiCLES

Alexander Keese Slow Abolition within the Colonial Mind:

British and French Debates about "Vagrancy", "African

Laziness", and Forced Labour in West Central and South Central

Africa, 1945-1965

Ad Knotter Transnational Cigar-Makers: Cross-Border

Labour Markets, Strikes, and Solidarity at the Time of the First

International (1864-1873)

Stefano Petrungaro Hostels for Jobless Workers in Interwar

Yugoslavia (I92 I-I94I)

Toby Matthiesen Migration, Minorities, and Radical

Networks: Labour Movements and Opposition Groups in

Saudi Arabia, I950-1975

\section{Book Reviews}

Technology, Skills and the Pre-Modern Economy in the East and the West. Essays dedicated to the memory of S.R. Epstein. Ed. by Maarten Prak and Jan Luiten van Zanden (Joel Mokyr)

Maria Luisa Pesante Come servi. Figure del lavoro salariato dal diritto naturale all'economia politica (Andrea Caracausi)

Alessandro Stanziani Bondage. Labor and Rights in Eurasia from the Sixteenth to the Early Twentieth Centuries (Peter Kolchin)

Timothy J. Coates Convict Labor in the Portuguese Empire, 1740-1932. Redefining the Empire with Forced Labor and New Imperialism (Christian G. De Vito)

Histories of Race and Racism. The Andes and Mesoamerica from

Colonial Times to the Present. Ed. by Laura Gotkowitz

(Paulo Drinot) 
The sexual history of the global South. Sexual Politics in Africa, Asia and Latin America. Ed. by Saskia Wieringa and Horacio Sívori (Peter Drucker)

Valerie G. Hall Women at Work, I860-I939. How Different Industries Shaped Women's Experiences (Elizabeth Roberts) Peter Ryley Making Another World Possible. Anarchism, Anti-Capitalism and Ecology in Late I9th and Early 20th Century Britain (Constance Bantman)

Paul Frölich Im radikalen Lager. Politische Autobiographie I 890-I 92 I (Ralf Hoffrogge)

Elizabeth McKillen Making the World Safe forWorkers. Labor, the Left, and Wilsonian Internationalism (Melvyn Dubofsky)

Eszter Bartha Alienating Labour. Workers on the Road from Socialism to Capitalism in East Germany and Hungary (Goran Musić)

Zewde Bahru The Quest for Socialist Utopia. The Ethiopian Student Movement c.1960-I974 (Samuel Andreas Admasie)

BibliogRAPHY

REFEREES 20II-20I3

ERRATUM

John S. Ahlquist and Margaret Levi In the Interest of Others. Organizations and Social Activism (Peter Cole) 